\title{
POLISEMI DALAM BAHASA TOLAKI
}

\author{
Oleh \\ Asrianingsih $^{1}$, Zalili Sailan' ${ }^{2}$, dan Marwati ${ }^{3}$ \\ ${ }^{1}$ Alumni Jurusan Pend. Bahasa dan Sastra Indonesia, ${ }^{2,3}$ Dosen Jurusan Pendidikan Bahasa \\ dan Sastra Indonesia, Fakultas Keguruan dan Ilmu Pendidikan \\ Universitas Halu Oleo
}

\begin{abstract}
ABSTRAK
Penelitian ini berjudul Polisemi dalam Bahasa Tolaki. Rumusan masalah dalam penelitian ini adalah bagaimanakah bentuk polisemi dalam bahasa Tolaki. Tujuan penelitian ini adalah untuk mendeskripsikan bentuk polisemi dalam kelas kata verba, adjektiva, nomina, dan adverbia. Penelitian ini termakasuk jenis penelitian deskriptif kualitatif dan metode penelitian lapangan. Data dalam penelitian ini berupa kosa kata bahasa Tolaki secara lisan maupun data yang ada dalam kamus. Pengumpulan data yang digunakan dalam penelitian ini adalah metode simak (observasi), metode cakap (wawancara), dan angket. Metode simak (observasi) adalah menyimak bahasa dari informan, sehingga metode ini diterapkan pada pembacaan kamus. Metode cakap (wawancara) adalah menanyakan kepada informan tentang kebenaran data yang ada dalam kamus tersebut. Sedangkan angket adalah teknik pengumpulan data dengan cara mengajukan pertanyaan tertulis untuk dijawab secara tertulis pula oleh responden. Data-data tersebut yang didapatkan dari sumber tertulis dicatat berdasarkan kelas kata verba terdiri dari, tekonda, lako, , mosalaki, pseudo, pewiso, tekoro, melele, dan sinimbi adjektiva terdiri dari, buna, ehe, magaga, meambo, dan mosa'a nomina terdiri dari, bungguno, holiwu, dan lohoro dan adverbia terdiri dari, auorunggi, dahu, lau-lau, dan nolia. Hasil penelitian ini menunjukan bahwa dalam bahasa Tolaki terdapat beberapa kata yang merupakan polisemi pada kelas kata verba, adjektiva, nomina dan adverbia. Polisemi merupakan kata yang memiliki makna lebih dari satu dan saling berkaitan.
\end{abstract}

\section{Kata Kunci: polisemi, bahasa Tolaki}

1 | Jurnal BASTRA (Bahasa dan Sastra), Vol. 4 No.1, Edisi JANUARI 2019/e-ISSN: 2503-3875/

http://ojs.uho.ac.id/index.php/BASTRA 


\section{PENDAHULUAN}

\subsection{Latar Belakang}

Bahasa dan masyarakat mempunyai hubungan yang sangat erat dan saling berkaitan satu sama lainnya. Karena bahasa merupakan lambang bunyi yang bersifat arbitrer yang digunakan oleh anggota kelompok masyarakat yang sama. Bahasa juga digunakan sebagai alat komunikasi maka seorang penutur bahasa sering dituntut untuk dapat berkomunikasi dalam fungsi yang berbeda-beda. Fungsi bahasa akan menghasilkan ragam bahasa yang berbeda pula. Bahasa Indonesia dapat berfungsi sebagai bahasa pertama dan bahasa kedua bagi bangsa Indonesia.

Demi kepraktisan berkomunikasi dan pendidikan anak-anak, keluarga menggunakan bahasa Indonesia sebagai bahasa pertama. Di samping itu, keluarga masa kini atau keluarga modern yang mempunyai bahasa ibu yang berbeda atau sama ada yang mengambil keputusan untuk menjadikan anaknya menjadi penutur bahasa asli bahasa Indonesia. Ini berarti bahwa jumlah pemakai bahasa Indonesia sebagai bahasa pertama semakin berkembang.

Tiap penutur pada dasarnya dapat memanfaatkan kedua ragam lisan dan ragam tulisan itu sesuai dengan keperluaanya, apapun latar belakangnya. Meskipun demikian, kita tidak dapat berharap orang yang kurang mendalam proses belajarnya mampu menggunakan ragam tulisan dengan keterampilan orang yang terpelajar. Pokok pelajaran di sekolah pada hakekatnya berkisar pada peningkatan keterampilan dalam kedua ragam lisan dan ragam tulisan itu.

Bahasa Tolaki adalah salah satu bahasa daerah yang ada di jazirah pulau Sulawesi Tenggara yang di pergunakanan oleh masyarakat penuturnya dan merupakan salah satu bahasa daerah yang mempunyai penutur yang cukup besar dan luas. Bahasa Tolaki merupakan bahasa yang hidup dan berkembang, yang digunakan oleh satu kelompok suku Tolaki sebagai bahasa pergaulan.

Semantik adalah telaah makna. Semantik menelaah lambang-lambang atau tanda-tanda yang menyatakan makna, hubungan makna yang satu dengan yang lain dan pengaruhnya terhadap manusia dan masyarakat. Oleh karena itu semantik, mencakup kata-kata, perkembangan dan perubahannya Tarigan, (2009: 7).

Dalam tata bahasa tradisional, kata adalah kesatuan bahasa terkecil yang mengandung arti atau makna. Dalam linguistik, tata bahasa struktural unsur bahasa terkecil adalah morfem. Morfem itu mengandung makna leksikal dan makna gramatikal.

Dalam penelitian ini, akan membahas tentang relasi makna. Ada beberapa relasi makna dalam studi

2 | Jurnal BASTRA (Bahasa dan Sastra), Vol. 4 No.1, Edisi Januari 2019/e-ISSN: 2503-3875/ http://ojs.uho.ac.id/index.php/BASTRA 
semantik yaitu sinonim, antonim, homonim, homograf, hiponim, ambiguitas dan polisemi. Di antara relasi-relasi makna tersebut polisemi merupakan kajian yang sangat menarik untuk diteliti. Karena, memiliki makna yang sangat ganda atau memiliki makna lebih dari satu, di mana maknamakna tersebut saling berhubungan satu sama lainnya. Selain itu polisemi merupakan relasi makna yang belum banyak diteliti oleh peneliti bahasa. Perbedaan polisemi dengan relasi makna yang lain yaitu polisemi merupakan kata-kata yang maknanya lebih dari satu.

Informasi menunjukan bahwa dalam bidang semantik, penelitian polisemi di dalam bahasa Tolaki belum diteliti. Oleh karena itu, perlu dilakukan penelitian untuk memperkaya khazanah kebahasaan. Alasan peneliti mengangkat judul polisemi dalam bahasa Tolaki adalah untuk mendeskripsikan bentuk kata verba, adektiva, nomina dan adverbia dalam bahasa Tolaki yang digunakan oleh masyarakat penuturnya.

Suhaemi (2002:

mengemukakan bahwa "polisemi berupa suatu bentuk yang memiliki makna lebih dari satu. Di antara makna tersebut masih ada hubungan tertentu meskipun hanya sedikit atau hanya bersifat kiasan. Polisemi juga merupakan kata-kata yang maknanya lebih dari satu. Oleh karena itu, makna-makna pada sebuah kata atau ujaran yang masih berkaitan satu dengan yang lainnya. Polisemi juga dapat diartikan sebagai makna yang sebenarnya yang dapat berhubungan dari satu makna, kemakna yang lainnya.

\subsection{Rumusan Masalah}

Bagaimanakah bentuk kata polisemi dalam bahasa Tolaki?

\subsection{Tujuan Penelitian}

Untuk mendeskripsikan bentuk kata polisemi dalam kelas kata verba, adjektiva, nomina dan adverbia dalam bahasa Tolaki.

\subsection{Manfaat Penelitian}

1. Penulis maupun pembaca mampu memperoleh pengetahuan dan pemahaman tentang bentuk Polisemi dalam Bahasa Tolaki.

2. Dokumentasi bahasa daerah sebagai bagian dari disiplin ilmu yang mesti terus dikembangkan khususnya bagi upaya pembinaan dan pengembangan bahasa daerah khususnya bahasa Tolaki.

3. Hasil penelitian ini diharapkan dapat digunakan sebagai masukan dan bahan bandingan mengenai kepolisemian sehingga dapat merangsang minat dan perhatian para ahli bahasa, praktisi, pemerhati bahasa, maupun peneliti selanjutnya untuk melakukan penelitian lanjutan. 


\subsection{Ruang Lingkup Penelitian}

Sesuai dengan masalah dan tujuan penelitian, maka penulis membatasi ruang lingkup penelitian berdasarkan bentuk polisemi. Bentuk polisemi dalam penelitian ini, adalah; (1) polisemi berbentuk kata dasar dan (2) polisemi berbentuk kata turunan pada kelas kata verba, adjektiva, nomina dan adverbia.

\subsection{Batasan Operasional}

1. Polisemi adalah sebuah leksem yang maknanya berbeda, tetapi masih berhubungan antara satu makna dengan makna yang lainnya.

2. Bahasa Tolaki merupakan bahasa yang hidup dan berkembang, yang digunakan satu kelompok suku bangsa sebagai bahasa sehari-hari.

3. Bentuk polisemi dalam penelitian ini membicarakan sebuah leksem yang mempunyai sebuah segi yang berbeda sesuai dengan konteks gramatikal yang melekatinya. Perubahan pemakaian ini menimbulkan polisemi.

\section{KAJIAN PUSTAKA}

\subsection{Semantik}

Kata semantik dalam Bahasa Indonesia (Inggris: semantics) berasal dari bahasa Yunani sema (kata benda yang berarti "tanda" atau "lambang". Kata kerjanya adalah semaino yang berarti "menandai" atau "melambangkan". Yang dimaksud dengan tanda atau lambang di sini sebagai padanan kata sema itu adalah tanda linguistik. Menurut Ferdinand de Saussure (1996), tanda terdiri atas (1) komponen yang mengartikan, yang berwujud bentuk-bentuk bunyi bahasa dan (2) komponen yang diartikan atau makna dari komponen yang pertama itu. Kedua komponen ini adalah merupakan tanda atau lamabang; sedangkan yang ditandai atau dilambanginya adalah sesuatu yang berada diluar bahasa yang lazim disebut referen atau hal yang ditunjuk (Chaer, 2013: 2).

"Di dalam linguistik, semar dihubungkan dengan peyampa.... makna oleh sarana-sarana gramatikal dan leksikal suatu bahasa. Berdasarkan pandangan penelitian linguistic yang bersifat teoretis, deskriptif, dan historis, maka masalah-masalah semantik yang masing-masing harus digarap adalah sifat-sifat ur..m..., sinkronis, atau dikronis." (Sills dalam Tarigan, 2009: 7).

Semantik adalah telaah makna. Semantik menelaah lambing-lambang atau tanda-tanda yang menyatakan mana, hubungan makna yang satu dengan yang makna yang lain, dan pengaruhnya terhadap manusia dan masyrakat. Oleh karena itu, semantik mencakup kata-kata, perkembangan dan perubahannya. Secara etimologi, kata semantik berasal dari bahasa Yunani semantickos 'penting; berarti', 
yang diturunkan pula dari semainein 'memperlihatkan; menyatakan 'yang berasal pula dari kata sema 'tanda' seperti yang terdapat pada kata semaphore yang berarti 'tiang sinyal yang dipergunakan sebagai tanda oleh kereta api'(Tarigan, 2009: 7).

Kata semantik ini kemudian disepakati sebagai istilah yang digunakan untuk bidang linguistik yang mempelajari hubungan antara tanda-tanda linguistik dengan hal-hal yang ditandainya. Atau dengan kata lain, bidang studi dalam linguistik yang mempelajari makna atau arti dalam bahasa. Oleh karena itu kata semantik dapat diartikan sebagai ilmu yang mempelajari tantang makna kata atau arti salah satu dari tiga tataran analisis bahasa: fonologi, gramatikal, dan semantik. Chaer (2013:2).

\subsection{Konsep Makna}

\subsubsection{Pengertian Makna}

Menurut kamus besar bahasa Indonesia (KBBI) makna merupakan maksud pembicara atau penulis; pengertian yang diberikan kepada suatu bentuk kebahasaan, jadi makna adalah suatu maksud ujaran yang diucapkan atau ditulis oleh seseorang. Makna merupakan suatu kata yang dapat berhubungan dengan kalimat agar maksud atau ujaran dapat dimengerti oleh pembaca. Saussure, (1994) (dalam Sarnia, 2015: 3) mengungkapkan "bahwa makna sebagia pengertian atau konsep yang dimiliki terdapat pada suatu tanda linguistik".

\subsubsection{Makna Leksikal}

Makna leksikal adalah makna yang dimiliki atau ada pada leksem meski tanpa konteks apapun. Misalnya, leksem pada kata kuda memiliki makna leksikal 'sejenis binatang berkaki empat yang biasa dikendarai'; pinsil bermakna leksikal 'sejenis alat tulis yang terbuat dari kayu dan arang'; dan air bermakna leksikal 'sejenis barang cair yang biasa digunakan untuk keperluan seharihari'. Oleh karena itu banyak orang yang mengatakan bahwa makna leksikal adalah makna yang ada dalam kamus (Chaer,2003: 289).

Marafad dan Sari (2015: 12) mengemukakan "bahwa makna leksikal merupakan makna yang berkaitan dengan leksikon seperti yang termuat didalam kamus.".Misalnya: gergaji = leksikonnya. Gergaji adalah lempengan besi yang salah satu sisinya bergerigi dan digunakan untuk memotong ( makna leksikalnya). Katakata yang memiliki makna sendiri tanpa dibantu oleh leksikon lain diantaranya: kata rumah, langit, lampu, lari,cahaya, dusun, laut, lesang, lezat, tidur, duduk.

\subsubsection{Makna Gramatikal}

Marafad dan Sari (2015: 12-13) mengemukakan bahwa makna gramtikal terjadi dalam struktur atau 
susunan unsur bahasa. Unsur bahasa yang memiliki makna gramatikal terdiri dari kata-kata tugas dan afiks, di antaranya: dengan, dan, sebab, karena, akan, sedangkan tetapi, walau, di, ke, dari, ber-, di-.Misalnya, kata dengan tidak memiliki makna apa-apa.Akan tetapi, bila kata dengan itu berada di dalam struktur lebih besar, maka kata itu memiliki makna, namanya makna gramatikal/makna struktur. Contohnya, Ayah berjalan dengan ibu. Kata berjalan = bersama. Inilah yang disebut dengan makna yang gramatikal/makna struktur.

\subsection{Polisemi}

\subsubsection{Pengertian Polisemi}

Menurut (Ullmann, 2014: 202) memaparkan "bahwa polisemi merupakan suatu unsur fundamental tutur manusia yang dapat muncul berbagai cara". Sebuah kata atau satuan ujaran disebut polisemi kata itu mempunyai makna yang lebih dari satu. Umpamanya, kata kepala yang setidaknya mempunyai makna (1) bagian tubuh manusia contohnya: kepalanya luka kena pecahan kaca.

Subroto, (2011: 74) memaparkan "bahwa polisemi adalah sebuah kata (baca: leksem) yang memiliki beberapa makna (poly berarti 'banyak' dan semem berarti 'arti') bergantung pada kontek kalimatnya.

\subsubsection{Homonim}

Menurut (Chaer, 2003: 302) menyatakan "bahwa homonim adalah dua buah kata atau satuan ujaran yang bentuknya "kebetulan" sama; maknanya tentu berbeda, karena masing-masing merupakan kata atau bentuk ujaran yang berlainan". Jika dua kata mempunyai bunyi yang identik dengan makna yang tidak terlalu besar kita cenderung mengatakan sebagai sebuah kata yang mempunyai suatu makna.

\subsubsection{Perbedaan Polisemi dan Homonim}

Polisemi menurut pengertian yang telah disebutkan diatas, adalah suatu bentuk atau makna kata yang mempunyai makna lebih dari satu (makna ganda), sedangkan homonim dapat diartikan sebagai kata yang sama lafal dan ejaannya, tetapi berbeda maknanya karena berasal dari sumber yang berbeda.

\subsubsection{Sumber-Sumber Polisemi}

Polisemi adalah ciri fundamental suatu bahasa yang keberadaanya disebabkan oleh berbagai faktor. Ullmann dalam (Suhaemi, 2002: 47) menyebutkan sekurang-kurangnya ada lima sumber polisemi, yakni:

1. Pergeseran penerapan (shifts in application)

2. Spesialisasi di dalam lingkungan sosial (specialization in a social milliew);

3. Bahasa figuratif (figurative languange); 
4. Penafsiran kembali pada pasangan yang homonym (homonyms reinterpreted);

5. Penafsiran bahasa lain.

\section{METODE DAN TEKNIK} PENELITIAN

\subsection{Metode dan Jenis Penelitian}

\subsubsection{Metode Penelitian}

Metode yang digunakan dalam penelitian ini adalah metode lapangan. Dikatakan metode lapangan karena data dalam penelitian ini pula berupa data lisan dari beberapa informan yang mengumpulkan dan mendapatkan data-data yang diperlukan dengan cara menelaah dan menganalisis polisemi dalam bahasa Tolaki.

\subsubsection{Jenis Penelitian}

Jenis yang digunakan dalam penelitian ini adalah deskriftif kualitatif. Deskriftif yakni suatu metode yang menggambarkan data secara alamiah serta menghasilkan kaidah kebahasaan.

\subsection{Data dan Sumber Data}

\subsubsection{Data Penelitian}

Secara lokasional berasal data penelitian dari konteks dan infoman. Sumber data secara primer adalah makna kata polisemi yang ada dalam bahasa Tolaki, sedangkan sumber data sekunder adalah menurut kamus bahasa Tolaki yang dibuktikan oleh informan yang berada di Desa Lalobao, Kecamatan Andoolo, Kabupaten Konawe Selatan, sehubungan dengan data penelitian berupa data lisan, maka sumber data dalam penelitian ini diperoleh dari masyarakat yang dipilih oleh informan.

\subsubsection{Sumber Data}

Sumber data yang digunakan dalam penelitian ini yaitu pemilihan kamus bahasa tolaki sebagai data dan sumber data dalam penelitian ini mengacu pada pendapat Saussure dalam Ekoyantiasih (2007: 7) yang menyatakan bahwa data penelitian yang sahih dalam penelitian bahasa secara sinkronis adalah kenyataan bahasa yang terimpan dalam langue.

\subsection{Metode dan Teknik Pengumpulan Data \\ Pengumpulan data yang} digunakan dalam penelitian ini adalah metode simak (observasi), metode cakap (metode wawancara) dan angket.

\subsection{Teknik Analisis Data}

Analisis data dilakukan melalui tahapan-tahapan sebagai berikut: (1) identifikasi data maksudnya menyeleksi data yang diperoleh atau memilih data yang sesuai dengan maksud dan tujuan penelitian: (2) klasifikasi data, maksudnya data yang diperoleh dibagi menjadi tiga kelompok analisis yaitu kelompok verba berpolisemi, kelompok adjektiva berpolisemi, kelompok nomina berpolisemi, dan kelompok adverbia

7 | Jurnal BASTRA (Bahasa dan Sastra), Vol. 4 No.1, Edisi Januari 2019/e-ISSN: 2503-3875/ http://ojs.uho.ac.id/index.php/BASTRA 
berpolisemi. Data-data tersebut dianalisis setu persatu sesuai tujuan penelitian: (3) menginterpretasikan data, yaitu suatu proses penafsiran data yang telah di klarifikasi.

\section{HASIL PENELITIAN DAN PEMBAHASAN}

\section{Data I: Verba ( kata kerja )}

Verba Dasar : -tekonda bermakna; terkurung, tertahan -lako bermakna;

pergi sama jalan -mosalaki

bermakna; membuat kesalahan, dibenci

$$
\text { -pesudo }
$$

bermakna; bertopang, saling berharap

$$
\text { -pewiso }
$$

bermakna; menusuk, masuk

$$
\text { -tekoro }
$$

bermakna; membesar tumbuh

$$
\text { -melele }
$$

bermakna; berlari, gesit

$$
\text { -sinimbi }
$$

bermakna; disambung, ditambah

$$
\text { Verba Turunan: -ale' } i
$$

bermakna; ambilkan, menjemput

$$
\text { -mosale'i }
$$

bermakna; membabat, memaras

-merodo

bermakna; melempar, terpelanting -mebinda

bermakna; berangkat, melepaskan diri -nibinda

bermakna; dilepas, dicerai.

\section{Data II: Adjektiva ( kata sifat )}

Adjektiva Dasar: -buna

bermakna; murah, gampang

$$
\text { -ehe }
$$

bermakna; suka, setuju

bermakna; ganteng, cantik

$$
\text { -magaga }
$$

-meambo

bermakna; baik, bagus

-mosaa

bermakna; tidak baik, jelek.

Adjektiva Turuna: -memeita bermakna; tertinggi (sesuai konteks)

\section{Data III: Nomina ( kata benda )}

Nomina Dasar: -bungguno bermakna; punggung, daerah di belakang kampong -holiwu

bermakna; selimut, kelambu -lohoro

bermkana; dzuhur, waktu tengah hari.

\section{Data IV: Adverbia ( kata keterangan )}

Adverbia: -auorunggi bermakna; cepat-cepat, segera -lau-lau bermakna; langsung, tiba-tiba -nolia bermakna; lebih, terlalu. 


\subsection{Bentuk Polisemi Bahasa Tolaki}

\subsubsection{Polisemi Berdasarkan Kategori} Kata

Polisemi berdasarkan kategori kata adalah meninjau kembali makna, berdasarkan konsep kategori kata atau berdasarkan kelas katanya. Pada dasarnya kata termaksud dalam kategori sintaksis dan tidak sekaligus masuk dalam kategori yang lain. Misalnya dalam bahasa Tolaki, kata siru, pade, piso, termaksud kategori nomina. Namun ada juga kata yang memiliki makna ganda. Data dalam bahasa Tolaki, kata seperi gondi 'kunci' termkasud kategori nomina. Misalnya dalam kalimat ale'i kona gondi ituo ' ambilkan saya kunci itu', sekaligus kategori verba, misalnya dalam kalimat gondi'i ituo kamara ' kunci itu kamar'.

Dalam penelitian ini kata yang akan dibahasa adalah (1) polisemi verba, (2) polisemi adjektiva, (3) polisemi nomina dan (4) polisemi adverbia. Adapun keempat jenis polisemi tersebut akan diuraikan sebagai berikut.

\subsection{Polisemi Verba Bahasa Tolaki 4.2.1 Polisemi Verba Dasar Bahasa Tolaki}

Berdasarkan kategorinya, ada beberapa polisemi verba dasar bahasa Tolaki. Dalam analisis data polisemi verba dasar Tolaki. Adapun makna kata tersebut sebagia berikut.
1. Tekonda bermakna: Terkurung, tertahan

2. Lako bermakna; pergi, jalan Verba dasar pertama adalah verba dasar tekonda yang memiliki dua makna yang berbeda. Adapun perbedaan makna tersebut adalah:

(1) tekonda bermakna : 1) tertahan;

2) terkurung;

Pembuktian hubungan polisemi pada verba tekonda tersebut dapat dilihat berdasarkan kalimat (1) dan (2) sebagai berikut:

1. I Rika no tekonda I laikano mbu eno

Rika $3 T$ tertahan prep rumah nenek-pss.

Rika tertahan di rumah neneknya

2. Sapino I Ani, no tekonda I bunggu laika

Sapi-pss Ani $3 T$ terkurung prep belakang rumah

Sapinya Ani terkurung di belakang rumah.

Kalimat tersebut memperlihatkan pemakaian verba tekonda yang memiliki makna yang berbeda tetapi saling berkaitan. Perbedaan makna tersebut dapat dihubungkan antara makna yang menghubungkan keduanya. Makna kata tekonda pada kalimat (1) 'tertahan' dengan pembuktian kalimat 'Rika tertahan di rumah neneknya' atau 'Rika terkekang di rumah neneknya'. Selanjutkan makna kata tekonda pada kalimat (2) 'terkurung' dengan pembuktian

9 | Jurnal BASTRA (Bahasa dan Sastra), Vol. 4 No.1, Edisi Januari 2019/e-ISSN: 2503-3875/ http://ojs.uho.ac.id/index.php/BASTRA 
kalimat 'Sapinya Ani terkurung dibelakang rumah' atau 'sapi Ani terkekang di belakang rumah'.

Uraian tersebut menunjukan bahwa kedua kalimat tersebut samasama memiliki makna 'terkekang' dimana pada kalimat (1) Rika tertahan di rumahnya neneknya. Kata tertahan pada kalimat tesebut memiliki makna 'terkekang'. Selanjutnya untuk kalimat (2) Sapinya Ani terkurung dibelakang rumah. Kata terkurung pada kalimat tersebut bermakna sapinya Ani terkurung atau terkekang di belakang rumah.

Dengan demikian, hubungan makna keduanya dapat diterima secara nalar sehingga kata tekonda merupakan polisemi. Dalam hal ini 'tertahan' berkedudukan sebagai makna pusat, sedangkan kata 'terkurung' adalah makna turunan yang dikembangkan dari makna 'tertahan'. Oleh karena itu, kata tekonda merupakan polisemi.

Verba selanjutnya adalah verba lako yang memiliki dua maknya yang berbeda tetapi saling berkaitan atau berhubngan. Adapun makna tersebut sebagai berikut:

Lako bermakna: 1) pergi;

2) jalan

Pembuktian hubungan polisemi pada verba 'lako tersebut dapat dilihat berdasarkan kalimat (1) dan (2) sebagai berikut:

1. I Ani no lako i dhaowa mooli o ika
Ani $3 T$ pergi prep pasar membeli ikan.

2. Oto no i ani lako ito ari mowingi dahu

Mobil-pss Ani sudah jalan dari tadi pagi

Mobil Ani sudah jalan dari tadi pagi.

Kalimat tersebut menunjukan dua kalimat yang memiliki makna yang berbeda tetapi saling berkaitan atau berhubungan. Makna verba 'lako' pada kalimat (1) adalah 'pergi', dengan pembuktian kalimat 'Ani pergi ke pasar membeli ikan'. Selanjutnya makna kata 'lako' pada kalimat (2) adalah 'jalan' dengan pembuktian kalimat 'Mobil Ani sudah jalan dari tadi pagi'. Kedua kalimat tersebut merupakan polisemi karena keduanya sama-sama memiliki makna 'bergerak meninggalkan suatu tempat' dapat terlihat pada pembuktian berikut. Pada kalimat (1) kata pergi ditunjukkan untuk manusia seperti dalam kalimat 'Ani pergi ke pasar membeli ikan'. Selanjutnya pada kalimat (2) Makna pada kalimat tersebut kata jalan ditujukan untuk kendaraan seperti pada kalimat berikut 'Mobil Ani sudah jalan dari tadi pagi'. Hubungan makna keduanya adalah meninggalkan suatu tempat dengn bukti kalimat (1) 'Ani pergi ke pasar membeli ikan' atau Ani meninggalkan tempatnya untuk pergi ke pasar membeli ikan. Selanjutnya kalimat (2) 'Mobil Ani sudah jalan 
dari tadi pagi' atau 'Mobil Ani sudah meninggalkan rumahnya atau tempatnya sejak pagi' secara tidak langsung kedua kalimat tersebut berpolisemi karena dihubungkan oleh makna 'meninggalkan suatu tempat'.

\subsubsection{Polisemi Verba Turunan Bahasa Tolaki}

Verba turunan pertama adalah verba turunan ale' $i$ yang memiliki dua makna berbeda. Kalimat verba turunan ale' $i$ dapat dilihat dibawah ini sebagai berikut:

1. Ale'i kona po'ombia ronga apiapino $i$ wawo meda

Ambil-sf rokok dan korek prep atas meja

Ambilkan rokok dan korek di atas meja

2. Iee nolako ale'i haino i laika sikola $3 T$ pergi jemput-sf adik-pss prep sekolah

Ia menjemput adiknya di sekolah

Verba turunan ale' $i$ berasal dari kata dasar alee yang berarti 'ambil dan jemput'. Makna kata ale'i pada kalimat (1) adalah Ambilkan rokok dan korek di atas meja. Makna kata ale'i pada kalimat (2) Ia menjemput adiknya di sekolah. Kedua makna tersebut adalah kalimat yang memiliki makna yang berbeda tetapi saling berhubungan. Dimana hubungan makna kedua kalimat tersebut adalah 'mendapatkan'. Pada kalimat

ambilkan rokok dan korek di atas meja atau dapatkan rokok dan korek di atas meja. Selanjutnya pada kalimat (2) Ia menjemput adiknya di sekolah memiliki makna sosok ia pergi mendapatkan adiknya di sekolah. Kedua kalimat tersebut merupakan polisemi. Karena, kata ale'i memiliki makna 'ambilkan' sebagai makna pertama sedangkan makna kata 'menjemput' sebagai makna kedua. Hubungan makna keduanya dapat diterima secara nalar sehingga makna ale' $i$ merupakan polisemi.

\subsection{Polisemi Adjektiva Bahasa \\ Tolaki}

\subsubsection{Polisemi Adjektiva Dasar Bahasa Tolaki}

Bukti hubungan polisemi pada adjektiva dasar buna dapat dilihat berdasarkan kalimat di bawah ini:

\section{Po'oli nggiro'o purorembu te'embe} olino no buna

Beli sayur itu sebab harga-pss murah.

Beli sayur itu sebab harganya murah.

2. Indi'ono banggonamu kadu ito no buna

Pekerjaan-pss teman-pss sangat gampang.

Pekerjaanya temanmu sangat gampang.

Adjektiva dasar memiliki makna yang berbeda. Namun, kedua kalimat tersebut dapat dihubungkan. Kedua kalimat di atas merupakan adjektiva dasar buna. Dari kedua kalimat di atas makna 'murah' dan 'gampang' adalah

11 I Jurnal BASTRA (Bahasa dan Sastra), Vol. 4 No.1, Edisi Januari 2019/e-ISSN: 2503-3875/ http://ojs.uho.ac.id/index.php/BASTRA 
'sama-sama mudah didapatkan'. Makna kata pada kalimat (1) beli sayur itu karena harganya murah atau beli sayur itu karena mudah didapat. Selanjutnya makna kalimat (2) pekerjaannya temanmu sangatlah gampang atau mudah di dapat pekerjaanya.

Adjektiva dasar buna merupakan polisemi. Karena makna tersebut sama-sama saling berkaitan atau berhubungan. Dengan demikian polisemi kedua kalimat tersebut dapat diterima secara nalar. Uraian ini menunjukan bahwa adjektiva dasar 'buna' merupakan polisemi.

\subsubsection{Polisemi Adjektiva Turunan Bahasa Tolaki}

Dalam polisemi bahasa Tolaki adjektiva turunan yaitu memeita dengan kata dasar meita. Untuk membuktikan bahwa adjektiva turunan memeita adalah polisemi, dapat kita lihat dengan contoh kalimat sebagai berikut:

1. Nopemberehuki pangga memeita $i$ kandorono

$3 T p f$-duduki pangkat $p f$-tinggi prep kantor-pss

Dia menduduki pangkat tertinggi di kantornya.

2. Nopodapa nilai memeita i kalasino $3 T$ pf-dapatkan nilai $p f$-tinggi prep kelas-pss.

Dia mendapatkan nilai tertinggi di kelasnya.
3. Ie ana sikola pali memeita $i$ nekalasino

$3 T$ adalah siswa $p$-tinggi prep kelas-pss.

Dia adalah siswa tertinggi di kelasnya.

Kalimat tersebut memperlihatkan adjektiva turunan memeita. Makna ketiga adjektiva turunan di atas memiliki konteks yang berbeda yang memiliki hubungan makna 'tinggi'. Hubungan makna tersebut dapat dibuktikan pada penjelasan berikut.

Makna kata memeita pada kalimat (1) adalah 'tinggi jabatan' dengan contoh kalimat 'dia menduduki pangkat tertinggi di kantornya atau ia menduduki jabatan tertinggi di kantornya'. Makna kata (2) adalah 'tinggi nilai' dengan contoh kalimat 'dia mendapatkan nilai tertinggi di kelasnya atau dia mendapatkan hasil usaha tertinggi di kelasnya'. Selanjutnya makna kata (3) adalah 'tinggi postur tubuh' dengan pembuktian kalimat 'dia adalah siswa tertinggi di kelasnya atau dia siswa yang memiliki postur tubuh tertinggi di kelasnya'.

Dengan demikian ketiga kalimat di atas dapat diterima secara nalar karena, menunjukan adanya polisemi. Hal ini ketiga kalimat di atas merupakan makna ganda dari satu bentuk kata yang sama yaitu memeita dan berasal dari kelas kata yang sama pula yaitu adjektiva. 


\subsection{Polisemi Nomina Bahasa Tolaki}

\subsubsection{Polisemi Nomina Dasar Bahasa}

\section{Tolaki}

Nomina dasar pertama adalah nomina dasar bungguno yang memiliki makna lebih dari satu. Dengan pembuktian kalimat sebagai berikut:

1. Wawo bungguno nggiro'o tono no mowaka

Atas punggung-pss lelaki itu $3 T p f-$ luka.

Atas punggungnya lelaki itu terluka.

2. Nggiro'o tono no lako moalo o kasu i bungguno

Orang sana $3 T$ pergi $p f$-ambil kayu prep kebun.

Orang sana pergi mengambil kayu di kebun.

Pemakaian nomina dasar bungguno pada kalimat tersebut memiliki makna yang berbeda. Hubungan makna keduanya adalah 'ke arah belakang'. Makna kata bungguno pada kalimat (1) adalah 'punggung' dengan contoh kalimat 'atas punggung lelaki itu terluka atau punggung lelaki itu terluka ke arah belakang'. Selanjutnya pada kalimat (2) adalah 'daerah di belakang kampong atau kebun' dengan pembuktian kalimat 'orang sana pergi mengambil kayu di kebun atau orang sana pergi ke arah belakang mengambil kayu.

\subsection{Polisemi Adverbia Bahasa Tolaki}

Adverbia pertama adalah adverbia auorunggi. Adverbia auorunggi juga merupakan polisemi. Dapat kita lihat dengan pembuktian kalimat dibawah ini:

1. Keno dungguto oliwi ari ine inamu auorunggi tumeninggona

Kalau sudah tiba kiriman dari ibupss segeralah memberitahu-pss.

Kalau sudah tiba kiriman dari ibumu segeralah memberitahuku.

2. Auorunggi pasadia'i tasi sikolahmu

Cepat-cepat sediakan tas sekolahpss.

Cepat-cepat sediakan tas sekolahmu.

Kalimat tersebut adalah kalimat adverbia yang memiliki makna lebih dari satu. Kedua kalimat tersebut sama-sama memiliki makna 'lekaslah atau tidak lama-lama'. Makna pada kalimat (1) kalau sudah tiba kiriman dari ibumu, segera-lah memberitahuku atau kalau sudah tiba kiriman dari ibumu, lekaslah untuk memberitahu. Selanjutnya makna pada kalimat (2) cepat-cepatlah sediakan tas sekolahmu atau lekaslah menyediakan tas sekolahmu. Dengan demikian, hubungan makna keduanya dapat diterima secara nalar sehingga, adverbia auorunggi merupakan polisemi. 
Hubungan makna keduannya adalah 'ke arah belakang' sehingga dapat diterima secara nalar bahwa makna kata bungguno merupakan polisemi yang memiliki makna lebih dari satu.

\section{PENUTUP}

\subsection{Simpulan}

Polisemi dalam Bahasa Tolaki dapat dibedakan berdasarkan bentuk kategori atau kelas katanya. Berdasarkan kategori kelas katanya, Polisemi dalam Bahasa Tolaki menjadi empat bagian yaitu (1) polisemi verba, (2) polisemi adjektiva, (3) polisemi nomina, dan (4) polisemi adverbia. Dalam penelitian ini disajikan beberapa polisemi verba dasar dalam bahasa Tolaki yaitu tekonda, lako, , mosalaki, pseudo, pewiso, tekoro, melele, dan sinimbi. Data polisemi berkelas kata verba turunan dalam bahasa Tolaki adalah ale' $i$, mosale' $i$, merodo, mebinda, dan nibinda. Selanjutnya data polisemi berkelas kata adjektiva dasar bahasa Tolaki adalah buna, ehe, magaga, meambo, dan mosa'a. Data polisemi berkelas kata adjektiva turunan adalah memeita. Data polisemi berkelas kata nomina dasar dalam bahasa Tolaki adalah bungguno, holiwu, dan lohoro. Selanjutnya data polisemi berkelas kata nomina turunan. Kemudian data polisemi adverbia dasar dalam bahasa
Tolaki auorunggi, dahu, lau-lau, dan nolia.

Kata-kata polisemi verba, adjektiva, nomina, dan adverbia dalam bahasa Tolaki tersebut memiliki makna lebih dari satu. Masing-masing makna tersebut saling berkaitan satu sama lainnya karena dihubungkan oleh makna yang secara langsung memiliki kesamaan. Polisemi juga memiliki makana pusat dan makna turunan.

\subsection{Saran}

Melalui penelitian ini, peneliti menyarankan bagi para peneliti selanjutnya khususnya mahasiswa agar senantiasa memeperlihatkan bahasa daerah dan menjadikan sebagai bahan penelitian agar dapat terhindar dari kepunahan. Penelitian ini dilakukan dengan mewawancai informan dengan pertanyaan kata-kata polisemi dan berpotensi yang terdapat dalam kamus bahasa Tolaki. Hasil data menunjukan tidak semua makna atau kata-kata tersebut diketahui dan digunakan oleh informan. Hal ini menimbulkan pendapat bahwa kemungkinan ada kata-kata di luar pertanyaan peneliti yang termaksud polisemi.

Peneliti menyadari bahwa penelitian ini merupakan bagian kecil dari kelas kata bahasa Indonesia. Karena hanya membahas polisemi kelas kata verba (kata kerja), kelas kata nomina (kata sifat), kelas kata nomina (kata benda), dan adverbia 
(kata dasar keterangan). Dengan demikian Polisemi dalam Bahasa Tolaki pada kategori kata yang lain masih belum diteliti sehingga, dapat dijadikan bahan penelitian lebih lanjut.

\section{DAFTAR PUSTAKA}

Alwi, Hasan, dkk. 2003. Tata Bahasa Baku Bahasa Indonesia. Jakarta: Pusat Bahasa dan Balai pustaka.

Aminuddin. 2011. Pengantar Studi Tentang Makna. Bandung: Sinar Baru Algesindo.

Chaer, Abdul. 2003. Linguistik Umum. Jakarta: PT Rineka Cipta.

Chaer, Abdul. 2013. Pengantar Semantik Bahasa Indonesia. Jakarta: PT Rineka Cipta.

Ekoyanantiasih, Ririen, dkk. 2007. Polisemi Verba dalamBahasa Melayu Betawi. Jakarta: Pusat Bahasa

Muhammad. 2011. Metode Penelitian Bahasa. Jakarta: AR-Ruzz Media

Murafad, Sidu dan Nirmala Sari. 2015. Mutiara Bahasa. Yogyakarta: Pustaka Puitika.
Prawirasumantri, Abud, dkk. 1997. Semantik Bahasa Indonesia. Jakarta: Departemen Pendidikan dan Kebudayaan.

Sarmita \& Fahrudin Hanafi. 2017. Polisemi Dalam Bahasa Bajo. Jurnal Bastra Volume 1 Nomor 4.

Sarnia. 2015. Polisemi dalam Bahasa Muna. Jurnal Humanika Nomor 15,Vol. 3 Desember.

Subroto, Edi. 2011. Pengantar Studi Semantik dan Pragmatik. Surakarta: Cakrawala Media.

Suhaemi, 2002. Polisemi Dalam Bahasa Bali. Jakarta: Pusat Bahasa.

Tarigan, Henry G. 2009. Pengajaran Semantik. Bandung: Angkasa.

Ullmann, Stephen. 2014. Pengantar Semantik. Yogyakarta: Pustaka Pelajar.

Wayan, I Gde. 2002. Polisemi Dalam Bahasa Bali. Jakarta: Pusat Bahasa.

Tim Penyusun. 2012. Kamus Dwibahasa Tolaki-Indonesia. Sulawesi Tenggara: Kantor Bahasa Sulawesi Tenggara. 